Review Article

www.ijrap.net

\title{
THERAPEUTIC BENEFITS OF HOLY BASIL (TULSI) IN GENERAL AND ORAL MEDICINE: A REVIEW Bhateja Sumit $^{1 *}$, Arora Geetika ${ }^{2}$ \\ ${ }^{1}$ Department of Oral Medicine Diagnosis and Radiology, Dr. DY Patil Dental College and Hospital, Pune, Maharashtra, India \\ ${ }^{2}$ Department of Public Health Dentistry, Vyas Dental College, Jodhpur, Rajasthan, India
}

Received on: 14/08/12 Revised on: 17/10/12 Accepted on: 05/11/12

\author{
*Corresponding author \\ E-mail: bhateja.sumit@gmail.com \\ DOI: 10.7897/2277-4343.03611 \\ Published by Moksha Publishing House. Website www.mokshaph.com \\ All rights reserved.
}

\section{ABSTRACT}

Nature has bestowed on us a very rich botanical wealth and a large number of diverse types of plants grow in different parts of the country. Plants are the richest resource of drugs in traditional systems of medicine, modern medicines, nutraceuticals, food supplements, folk medicines, pharmaceutical intermediates and chemical entities for synthetic drugs. Medicinal plants are a source of great economic value all over the world. Ocimum sanctum Linn (Tulsi) is a well-known plant used in the Indian system of medicine. This paper reviews the therapeutic potential of this plant in treatment of various medical and oral disorders.

Keywords: Tulsi, Ocimum sanctum Linn, Oral medicine, Medicinal plant

\section{INTRODUCTION}

In recent times, focus on plant research has increased all over the world and a large body of evidence has collected to show immense potential of medicinal plants used in various traditional systems. The use of plants and plant products as medicines could be traced as far back as the beginning of human civilization. The earliest mention of medicinal use of plants in Hindu culture is found in "Rigveda", which is said to have been written between 4500 - $1600 \mathrm{BC}$ and is supposed to be the oldest repository of human knowledge. ${ }^{1}$ Today the large number of drugs in use are derived from plants, like morphine from Papaver somniferum, Aswagandha from Withania somnifera, Ephedrine from Ephedra vulgaris, Atropine from Atropa belladonna, Reserpine from Rauwolfia serpentina etc. The medicinal plants are rich in secondary metabolites (which are potential sources of drugs) and essential oils of therapeutic importance. The important advantages claimed for therapeutic uses of medicinal plants in various ailments are their safety besides being economical, effective and their easy availability., ${ }^{2,3}$

Ayurveda, which means science of long life, is at least a 5000 year old system of Indian medicine (1500-1000 BC) designed to promote good health and longevity rather than to fight disease and was practiced by physicians and surgeons (called bheshaja or vaidya). Until 700 B.C. this science was orally discussed between sages and physicians. ${ }^{4}$ In Ayurveda, Tulsi has been well documented for its therapeutic potentials and described as Dashemani Shwasaharni (antiasthmatic) and Kaphaghna (Anti-cough). ${ }^{2}$

\section{Tulsi's History and Mythology in India}

Tulsi in Sanskrit means "one that is incomparable or matchless". Tulsi was recognized thousands of years ago by ancient Rishis to be one of the India's greatest healing herbs. They saw this herb is so good for health and healing that it was declared as a God in itself. Tulsi is a herb with its own mythological background. It is supposed to be beloved of Lord Krishna, a reincarnation of Lord Vishnu. Tulsi was then established as one of the eight indispensable items in any Vedic worship ritual to ensure that every house and temple had atleast one Tulsi bush in its proximity. Still today Tulsi can be found planted in most homes in India and is most respected and honored herb due to its continuing importance in healing, religion, spirituality, culture and decorative aesthetics. It is so readily found now even in the West that one of its names is Sulabha 'the easy obtainable on'.

\section{Ocimum sanctum Linn (Tulsi): A plant from genus Ocimum}

Among the plants known for medicinal value, the plants of genus Ocimum belonging to family Labiatae are very important for their therapeutic potentials. Ocimum sanctum L. (Tulsi), Ocimum gratissium (RamTulsi), Ocimum canum (Dulal Tulsi), Ocimum basilicum (Ban Tulsi), Ocimum kilimandscharicum, Ocimum ammericanum, Ocimum camphora and Ocimum micranthum are examples of known important species of genus Ocimum which grow in different parts of the world and are known to have medicinal properties. Ocimum sanctum L. known as 'Tulsi' in Hindi and 'Holy Basil' in English is an erect softy hairy aromatic herb or undershrub found throughout India. Tulsi is commonly cultivated in gardens. Two types of Ocimum sanctum $L$. are met within cultivation: (i) Tulsi plants with green leaves known as 'Sri Tulsi' and (ii) Tulsi plants with purple leaves known as 'Krishna Tulsi'. Ocimum sanctum $L$. is held sacred by Hindus and is used as medicinal plant in day to day practice in Indian homes for various ailments. $^{6,7}$ 


\section{Pharmacological Actions}

Several medicinal properties have been attributed to Ocimum sanctum L. Different parts of Tulsi plant e.g. leaves, flowers, stem, root, seeds etc. are known to possess therapeutic potentials and have been used by traditional medical practitioners as expectorant, analgesic, anticancer, antiasthmatic, antiemetic, diaphoretic, antidiabetic, antifertility, hepatoprotective, hypotensive, hypolipidmic and antistress agents. Tulsi has also been used in treatment of fever, bronchitis, arthritis, convulsions etc. ${ }^{8}$ The following section discusses its various therapeutic uses in medicine and dentistry.

\section{MEDICAL USES}

\section{Gastrointestinal Disorders}

Aqueous decoction of Tulsi leaves is given to patients suffering from gastric and hepatic disorders. ${ }^{6,9}$ Herbal preparations containing Ocimum sanctum $L$. have been suggested to shorten the course of illness, clinical symptoms and biochemical parameters in patients suffering from viral hepatitis. Effective in increasing the peristaltic movements of GI tract. It is helpful in improving appetite. Also have some mild laxative properties therefore helps in evacuation of the bowel and maintenance of a healthy bowel. ${ }^{9}$ The juice of fresh leaves is also given to patients to treat chronic fever, dysentery, hemorrhage and dyspepsia. ${ }^{6,9}$ Tulsi leaves also check vomiting and has been as anthelmintic. Gastric ulceration and secretion are reported to be inhibited by Tulsi in albino rats. $^{8,10}$

\section{Eye (Ocular) Disorders}

The leaf juice of Ocimum sanctum L. along with Triphala is used in Ayurvedic eye drop preparations recommended for glucoma, cataract, chronic conjunctivitis and other painful eye diseases. 6,9

\section{Cardiovascular Disorders}

It has beneficial effect in cardiac diseases and the weakness resulting from the various cardiac disorders. It even reduces the level of blood cholesterol. Eugenol (extracted from Tulsi leaves) has been well shown to possess the vaso-relaxing action on rabbit arterial tissue indicating its therapeutic importance as a vasodilator. ${ }^{11,12}$

\section{Respiratory Disorders}

Tulsi is very effective in treating the common cold. A decoction of the leaves, with honey and ginger is an effective remedy for bronchitis, bronchial asthma, influenza, cough and cold. For the immediate relief in cases of Influenza the decoction of the leaves, cloves and common salt also gives immediate relief within the case of influenza. Tulsi is important constituent of many Ayurvedic cough syrups and expectorants. It helps to mobilize mucus in bronchitis and asthma thus is very beneficial for maintenance of a very healthy respiratory passage. Chewing Tulsi leaves relieves cold and flu. Water boiled with Tulsi leaves is taken as to drink in case of sore throat. This water can also be used for the purpose of gargles. ${ }^{8,13}$

\section{Renal Disorders}

Tulsi has strengthening effects on the kidney. In cases of renal stone the juice of Tulsi leaves and honey, if taken regularly for 6 months it will expel them through the urinary tract. Leaves and seeds of Tulsi plants have been reported to reduce blood and urinary uric acid level in albino rabbits and possess diuretic property. ${ }^{14}$ The fresh leaves and flower tops of Ocimum sanctum $L$. have been used as antispasmodic agent (as smooth muscle relaxant). ${ }^{6,8}$ The seeds are mucilaginous and demulcent and are given in disorders of the genitourinary system. ${ }^{6}$

\section{Dermatological Disorders}

Applied locally, Tulsi juice is beneficial in treatment of ringworm and other skin diseases. It is also very beneficial in skin disorders such as leucoderma. ${ }^{8}$

\section{Psychological Disorders}

Tulsi leaves are regarded as an "adaptogen" or antistress. Recent studies have shown that leaves provide its user with significant protection against stress. Even healthy persons can chew 12 leaves of Tulsi, twice a day to prevent stress. It even purifies the blood and helps prevent several common psychological disorders. ${ }^{15}$

\section{Diabetes Mellitus}

The leaves of Tulsi plant contain various essential oils within them. It is therefore very useful in improving pancreatic beta cell function and thus enhancing the insulin secretion to keep a check over the blood sugar within the patients suffering by diabetes. ${ }^{16}$

\section{Inflammatory Disorders}

Tulsi inhibits inflammation causing enzymes in our bodies which contribute to pain and other signs of inflammation. The anti-inflammatory effects of Tulsi are comparable to ibuprofen, naproxen and aspirin. Tulsi even enhances the adrenal function by lowering cortisol levels. This results in reducing the negative effects of stress. Tulsi is very effective in suppressing any kind of edema that happening in the body. It improves blood circulation in the body therefore helpful in dealing with any kind of swellings in the body. ${ }^{17}$

\section{Antifertility effect}

The leaves of Ocimum sanctum $L$. are said to have abortifacient effect in women. Ocimum sanctum $L$. has also got antifertility effect. Ursolic acid, one of the major constituents of the Tulsi leaves has been suggested to possess antifertility effect in rats of both sexes and in male mice. Ursolic acid because of its anti-estrogenic effect reduces spermatogenesis and causes a decrease in sperm counts. ${ }^{18,19}$

\section{Antitumor effect}

The seed oil of Ocimum sanctum was evaluated for chemo-preventive activity against subcutaneously injected 20 -methylcholanthrene induced fibrosarcoma tumors in the thigh region of Swiss albino mice. Supplementation of maximal tolerated dose $(100 \mathrm{ml} / \mathrm{kg}$ body weight $)$ of the oil significantly reduced 20-methylcholanthrene induced tumor incidence and tumor volume. The results of this study suggest that the potential chemopreventive activity of the oil is partly attributable to its antioxidant properties. The chemo-preventive efficacy of $100 \mathrm{ml} / \mathrm{kg}$ seed oil was comparable to that of $80 \mathrm{mg} / \mathrm{kg}$ of vitamin E. ${ }^{20}$

\section{Oro-Dental Uses \\ Oral Infections}

Tulsi leaves are quite effective in treating common oral infections. Also few leaves chewed help in maintaining oral hygiene. Carracrol and Tetpene are the antibacterial agents present in this plant. Sesquiterpene bcaryophyllene also severs the same purpose. This 
constituent is FDA approved food additive which is naturally present in Tulsi. ${ }^{21}$

\section{Toothache}

Tulsi can act as COX-2 inhibitor, like modern analgesics due to its significant amount of Eugenol (1 - hydroxyl 2methoxy - 4 allyl benzene) Ocimum sanctum leaves contain $0.7 \%$ volatile oil comprising about $71 \%$ eugenol and $20 \%$ methyl eugenol. ${ }^{22}$

\section{Periodontal Disorders}

Tulsi leaves dried in sun and powdered can be used for brushing teeth. It can also be mixed with mustard oil to make a paste and used as toothpaste. This is very good for maintaining dental health, counteracting oral malodor (halitosis). This can also be used for massaging gingiva to treat various gingival and periodontal diseases. ${ }^{21,22}$

\section{Anticariogenic Agent}

Streptococcus mutans is a microorganism which has been well implicated in causing dental caries. In an in-vitro study the various concentrations of the Tulsi extracts have been assessed against streptococcus mutans and concluded that the composition of Tulsi extract $4 \%$ has a maximum antimicrobial potential. ${ }^{21}$

\section{Candidiasis}

The antifungal activity of the essential oil of Ocimum sanctum and its two main components i.e. Eugenol and linalool have been investigated against two species of Candida (i.e. C. albicans and C. tropicalis) which are known to causes oral candidiasis in a study and concluded that linalool is more promising and effective against candidia. $^{23}$

\section{Lichen planus}

Ocimum sanctum have the unique property of acting on the skin and blood tissue and also bring about the desired immunomodulation and it one of the treatment options in Ayurveda for treating lichen planus. ${ }^{24}$

\section{Leukoplakia and Oral Submucous Fibrosis}

Polyphenol rosmarinic acid present in Tulsi can act as a powerful antioxidant so this property can therapeutically utilized in treating common oral precancerous lesions and conditions. $^{25,26}$

\section{Pemphigus}

Ayurvedic treatment aims at boosting the immune system and promotes healing of the blisters and sores. Due to its immunomodulating property Ocimum sanctum may find its potential use in treating immunologically mediated mucosal condition like pemphigus. ${ }^{27}$

\section{Apthous Ulcerations}

Ocimum sanctum at a dose of $100 \mathrm{mg} / \mathrm{kg}$ was found to be effective antiulcer agent in a study. Anti-ulcer effect of Ocimum sanctum may be due to its cytoprotective effect rather than antisecretory activity. Conclusively Ocimum sanctum is found to possess potent anti-ulcerogenic as well as ulcer-healing properties and could act as a potent therapeutic agent against peptic ulcer disease. This property may also prove beneficial in oral ulcers. ${ }^{28}$

\section{Nutrient}

Tulsi contains Vitamin A and C, calcium, zinc and iron. It also has chlorophyll and many other phytonutrients. Deficiency of these nutrients has been associated with variety of oral diseases. $^{29}$

\section{CONCLUSION}

Therapies involving plants have existed for thousands of years and some may be as old as human civilization itself. One such medicinal plant is "Tulsi" which is regarded as the "Queen of Herbs" because of its varied medicinal properties and mythological value too. Several pharmacological studies have established a scientific basis for therapeutic uses of this plant. Traditionally it has been used for treating various systemic conditions in Ayurveda. It can prove beneficial in treating oral diseases also because of its antibacterial, antiinflammatory, ulcer healing, antioxidant, immunomodulatory properties. Future studies should be directed to explore and evaluate therapeutic significance of this miraculous plant in oral medicine.

\section{REFERENCES}

1. Akerele . Summary of WHO Guidelines for the Assessment of Herbal Medicines Herbal Gram.1993; 22: 13-28.

2. Sirkar NN. Pharmacological basis of Ayurvedic therapeutics. In: Cultivation and utilization of medicinal plants. Editors: Atal CK and Kapoor BM (Published by PID CSIR) 1989.

3. Siddiqui HH. Safety of herbal drugs-an overview. Drugs News and Views 1993; 1(2): 7-10.

4. Sharma PV. Charaka samhita. Varanasi: Choukhamba Orientalia; 1981

5. Rai Y. Holy Basil: Tulsi (A Herb). Navneet Publications India Ltd. 2002.

6. Ocimum sanctum. The Indian home remedy. In: Current Medical Scene, March-April 1992(Edited and published by S. Rajeshwari, Cipla Ltd., Bombay Central, Bombay).

7. Pandey BP, Anita. In: Economic Botany (Published by Chand and Company Ltd., Ramnagar, New Delhi), pp. 294, 1990.

8. Sen P. Therapeutic potentials of Tulsi: from experience to facts. Drugs News and Views 1993; 1(2):15-21.

9. Pandey BP, Anita. In: Economic Botany (Published by Chand and Company Ltd., Ramnagar, New Delhi), pp. 294, 1990.

10. Mnadal S, Das DN, Dey K, et. al. Ocimum sanctum Linn - A study on gastric ulceration and gastric secretion in rats. Indian J Physiol Pharmacol 1993; 37: 91-92.

11. Sarkar A, Pandey DN, Pant MC. Changes in the blood lipid profile level after administration of Ocimum sanctum (Tulsi) leaves in the normal albino rabbits. Indian J Physiology Pharmacology1994; 38(4): 311-312.

12. Nishijima H, Uchida R, Kimiko K, Kawakami N,Ohkuba T, Kitamura K. Mechanisms mediating the vasorelaxing action of eugenol, pungent oil on rabbit arterial tissues. Jpn J Pharmacology 1999;79(3): $\quad 327-334 . \quad$ http://dx.doi.org/10.1254/ijp.79.327 PMid: 10230861

13. Nadkararni AK, Nadkarni KM. Indian Materia Medica (Published by Popular Prakashan Pvt. Ltd., Bombay) 1976.

14. Sarkar A, Pandey DN, Pant MC. A report on the effect of Ocimum sanctum (Tulsi) leaves and seeds on blood and urinary uric acid, urea and urine volume in normal albino rabbits. Indian J Physiol Pharmacology 1990; 34: 61-62.

15. Bhargava KP, Singh N. Antistress activity of Ocimum sanctum Linn. Indian J Medical Research 1981; 73: 443-451.

16. Nagarajun S, Jain HC, Aulakh GS. Indigenous plants used in the control of Diabetes. In: Cultivation and utilization of medicinal plants. Editors: Atal CK and Kapoor BM (Published by PID CSJR) 1989, pp. 584.

17. Gupta SK, Prakash J, Srivastava S. Validation of claim of Tulsi, Ocimum sanctum Linn as a medicinal plant. Indian J Experimental Biology 2002; 40(7): 765-773.

18. Batta SK, Santhakumari G. The antifertility effect of Ocimum sanctum and Hibiscuc Rosa Sinensis. Indian J Medical Research 1971; 59: 777-781.

19. Nagarajun S, Jain HC, Aulakh GS. Indigenous plants used in fertility control. In: Cultivation and utilization of medicinal plants. Editors: Atal CK and Kapoor BM (Published by PID CSIR) 1989, pp. 558. 
20. Prakash J, Gupta SK. Chemopreventive activity of Ocimum sanctum seed oil. J Ethnopharmacol 2000; 72: 29-34. http://dx.doi.org/10.1016/S0378-8741(00)00194-X

21. Agarwal P, Nageshl L, Murlikrishnan. Evaluation of the antimicrobial activity of various concentrations of Tulsi (Ocimum sanctum) extract against Streptococcus mutans: Ind J Dent Res 2010;21(3):357-59. http://dx.doi.org/10.4103/0970-9290.70800 PMid:20930344

22. Singh SA, Majumdar DK, Rehan HMS. Evaluation of ant inflammatory potential of fixed oil of Ocimum sanctum (Holybasil) and its possible mechanism of action. J Ethnopharmacol 1996; 54:19-26. http://dx.doi.org/10.1016/0378-8741(96)83992-4

23. Khan A, Ahmad A, Manzoor N and Khan L A .Antifungal activities of Ocimum sanctum Essential Oil and its Lead Molecules. Natura Products Communications 2010; 5(2):345-349.

24. Abdulmubeen Mundewadi. Ayurvedic Herbal treatment. Available athttp://EzineArticles.com/? expert=Abdulmubeen_Mundewadi(LP).
25. Leukoplakia and Tulsi. Available http://www.seacoast.com/topic.php?health=leukoplakia+and+tulsi 26. MP Bhattathiry. 15 Benefits of the Holy Basil (Tulsi). Available at http ://www.hinduism. com.

27. Mediratta PK. Evaluation of immunomodulatory potential of Ocimum sanctum seed oil and its possible mechanism of action $\mathrm{J}$ Ethnopharmacol 2002; 80:1 5-20.

28. Dharmani P. Evaluation of anti-ulcerogenic and ulcer-healing properties of Ocimum sanctum Linn. J Ethnopharmacol 2004; 93 197 -206. $\quad$ http://dx.doi.org/10.1016/j.jep.2004.02.029 PMid: 15234753

29. Tulsi Medicinal Ingredients. Available at http:/www.tulsiherbalte.

\section{Cite this article as:}

Bhateja Sumit, Arora Geetika. Therapeutic benefits of Holy Basil (Tulsi) in general and oral medicine: A Review. Int. J. Res. Ayur. Pharm. 2012; $3(6): 761-764$ 